\title{
The role of placental tryptophan catabolism
}

\author{
Peter Sedlmayr ${ }^{1}{ }^{*}$, Astrid Blaschitz ${ }^{1}$ and Roland Stocker ${ }^{2}$ \\ 1 Institute of Cell Biology, Histology and Embryology, Medical University of Graz, Graz, Austria \\ ${ }^{2}$ Victor Chang Cardiac Research Institute, Darlinghurst, NSW, Australia
}

Edited by:

Sinuhe Hahn, University Clinics Basel,

Switzerland

\section{Reviewed by:}

Francesca Fallarino, University of

Perugia, Italy

David Alexander Clark, McMaster

University, Canada

*Correspondence:

Peter Sedlmayr, Institute of Cell Biology, Histology and Embryology, Medical University of Graz, Harrachgasse 21, 8010 Graz, Austria

e-mail: peter.sedlmayr@

medunigraz.at
This review discusses the mechanisms and consequences of degradation of tryptophan (Trp) in the placenta, focusing mainly on the role of indoleamine 2,3-dioxygenase-1 (IDO1), one of three enzymes catalyzing the first step of the kynurenine pathway of Trp degradation. IDO1 has been implicated in regulation of feto-maternal tolerance in the mouse. Local depletion of Trp and/or the presence of metabolites of the kynurenine pathway mediate immunoregulation and exert antimicrobial functions. In addition to the decidual glandular epithelium, IDO1 is localized in the vascular endothelium of the villous chorion and also in the endothelium of spiral arteries of the decidua. Possible consequences of IDO1-mediated catabolism of Trp in the endothelium encompass antimicrobial activity and immunosuppression, as well as relaxation of the placental vasotonus, thereby contributing to placental perfusion and growth of both placenta and fetus. It remains to be evaluated whether other enzymes mediating Trp oxidation, such as indoleamine 2,3-dioxygenase-2, Trp 2,3-dioxygenase, and Trp hydroxylase-1 are of relevance to the biology of the placenta.

Keywords: pregnancy, placenta, intrauterine growth restriction, fetal growth restriction, preeclampsia, vasotonus, feto-maternal tolerance, immunoregulation

\section{INTRODUCTION}

$\mathrm{L}$-Tryptophan ( $\mathrm{L}-\operatorname{Tr} \mathrm{p})$ is a hydrophobic amino acid with a chemical structure based on an indole ring. $\mathrm{L}-\mathrm{Trp}$ is the least abundant essential amino acid, and therefore needs to be supplied by nutrients such as meat, fish, milk, eggs, vegetables, nuts, and seeds such as soybeans, sesame, and sunflower seeds. The daily requirement of adults is in the range of $3 \mathrm{mg} / \mathrm{kg}$ (1). Apart from protein synthesis, L-Trp is utilized for the synthesis of the neurotransmitter serotonin and the hormone melatonin in the pineal gland. Degradation of Trp in mammals occurs predominantly ( $>95 \%$ ) along the kynurenine pathway, leading to synthesis of nicotinamide adenine dinucleotide $\left(\mathrm{NAD}^{+}\right)$(2) (Figure 1).

The first step in the oxidative metabolism of $\mathrm{L}$-Trp along the kynurenine pathway is catalyzed independently by three different enzymes: indoleamine 2,3-dioxygenase-1 (IDO1), indoleamine 2,3-dioxygenase-2 (IDO2), and Trp 2,3-dioxygenase (TDO). By incorporating molecular oxygen, these enzymes convert L-Trp to $\mathrm{N}$-formyl-kynurenine, which is then converted to kynurenine. LTrp degradation not only leads to depletion of the amino acid but also to the production of metabolites displaying various biological activities.

\section{TRYPTOPHAN-DEGRADING ENZYMES INDOLEAMINE 2,3-DIOXYGENASE-1}

Indoleamine 2,3-dioxygenase-1 (IDO, indoleamine-pyrrole 2,3dioxygenase), reviewed in Ref. (3), is a cytosolic heme-containing enzyme sharing some sequence similarity with myoglobin (4). IDO1 has been conserved through 600 million years of evolution (5). The protein is encoded by the IDO1 (also INDO) gene that is located on chromosome 8 , contains 10 exons, and a promoter region that includes 2 interferon (IFN) - stimulated responsive elements. Human IDO cDNA encodes a protein of 403 amino acids with molecular weight of about $45 \mathrm{kDa}(6,7)$. The primary sequence of human IDO1 shows 57 and $58 \%$ identity to mouse and rat IDO1, respectively, whereas no sequence homology was found to rat TDO (8). IDO1 requires activation by reduction of its $\mathrm{Fe}^{3+}$-heme form. Early studies suggested that superoxide anion is responsible for this reductive activation (9), although more recent studies indicate formation of $\mathrm{Fe}^{2+}-\mathrm{IDO} 1$ is accomplished by cytochrome $b_{5}$ plus cytochrome $\mathrm{P} 450$ reductase and NADPH (10). Despite numerous studies, the mechanism by which IDO1 oxidizes L-Trp to $\mathrm{N}$-formyl-kynurenine remains controversial, with both concerted incorporation of the two oxygen atoms and consecutive insertions of single oxygen atoms into the substrate being proposed (11). $\mathrm{Fe}^{2+}$-IDO1 rapidly autoxidizes to the inactive $\mathrm{Fe}^{3+}$-IDO1 (12). In the presence of hydrogen peroxide $\left(\mathrm{H}_{2} \mathrm{O}_{2}\right)$, IDO1 takes on a peroxidase activity that can lead to the oxidation of L-Trp to oxyindolylalanine, and protein oxidation leading to IDO1 inactivation (13). IDO1 prefers L-Trp as a substrate but may also cleave D-Trp and other indoleamines such as tryptamine. In contrast to rabbit IDO, however, the human enzyme does not act on serotonin (14). 1-Methyltryptophan (1MT) is a compound commonly used to inhibit IDO1 activity, although it is now recognized that the enzyme is also capable of metabolizing 1-MT. The L-isoform of 1-MT has been reported to be a more efficient inhibitor of IDO1 than the D-isomer $(15,16)$. Further IDO inhibitors are discussed in $(17,18)$. INCB024360 and Amg-1 have been reported to block IDO1 selectively, with no effect on $\operatorname{IDO} 2$ and $\operatorname{TDO}(19,20)$.

In humans, high Trp-degrading activity has been described in the lung, the intestine, and particularly in the term placenta, where it was attributed to IDO1 (21). At that time, however, a possible contributory role of extrahepatic TDO and/or IDO2 was not envisaged. IDO1 is also detected in the mammalian epididymis, 


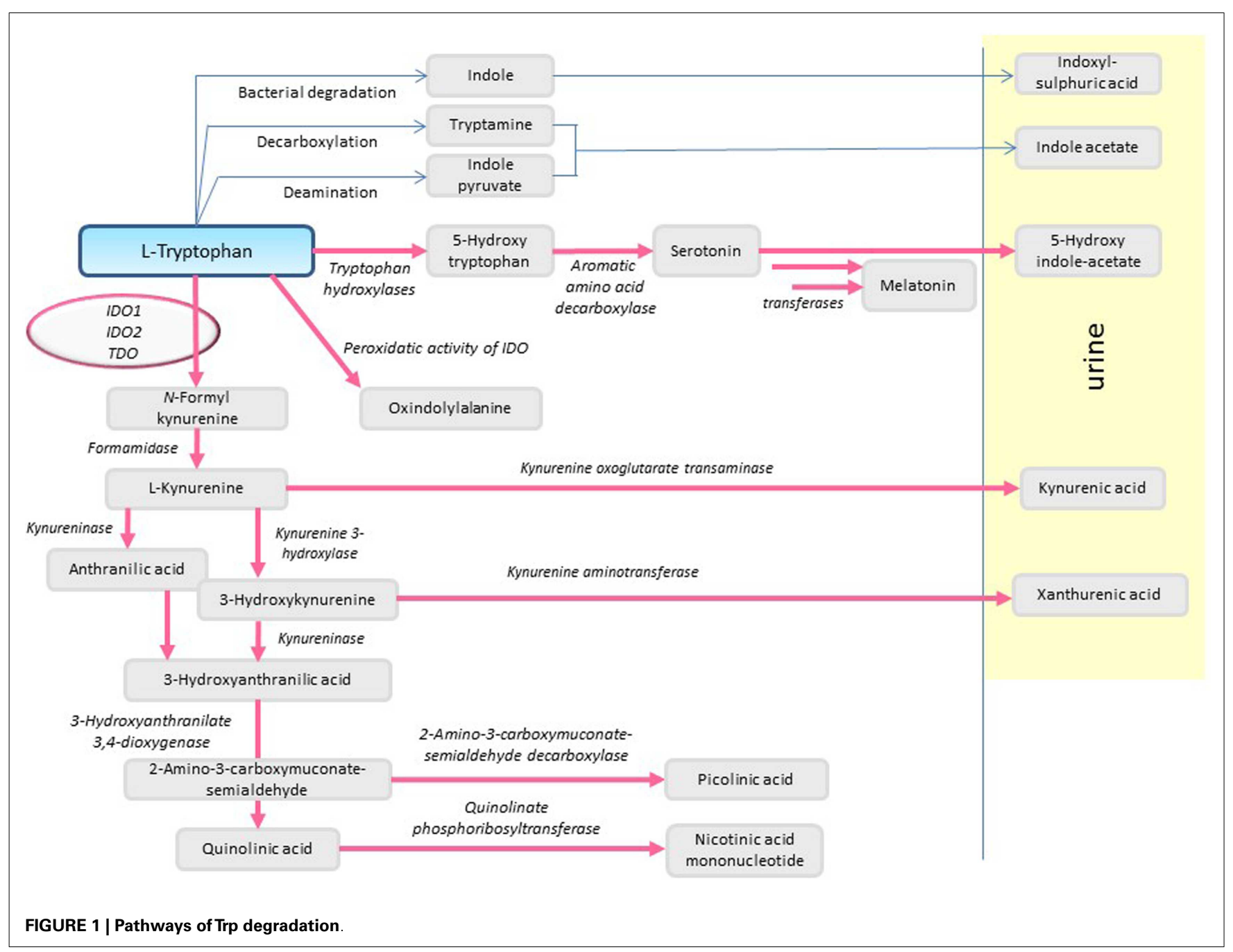

where its absence generates an inflammatory state and correlates with an increase in abnormal spermatozoa in IDO1 gene knockout $\left(\mathrm{IDO1}^{-/-}\right.$) mice (22). On a cellular basis, constitutive expression of IDO1 has been found in subsets of dendritic cells (DC) (23), including DC of tumor-draining lymph nodes (24). Moreover, IDO1 has been reported in eosinophils (25), in glandular and surface epithelium of the endometrium and Fallopian tubes (26), and in placental endothelial cells (26-28). IDO1 is also present in microvascular endothelial cells of tumors (29) (Blaschitz, unpublished observations for hepatocellular carcinoma) and the heart in human septic shock (30). Regulatory T cells have been reported to induce the expression of IDO1 in vascular endothelial cells of transplanted hearts in rats (31). Diverging inducibility of IDO1 has been reported for different types of normal endothelial cells, as summarized in Table 1.

Indoleamine 2,3-dioxygenase- 1 can be induced by IFN- $\gamma$ acting via Janus kinase (JAK)/signal transducer and activator of transcription (STAT) signaling, type I interferons, prostaglandin E2, lipopolysaccharide (LPS), DNA regions containing a high frequency of cytosine nucleotides adjacent to guanine nucleotides (CpG islands), and other factors in a variety of cell types such as DC, macrophages, epithelial and endothelial cells, Langerhans cells, astrocytes, and T lymphocytes. Also hormones such as estrogen (32) and human chorionic gonadotropin (hCG) (33-35) induce IDO1 expression. Upregulation of IDO1 in DC by hCG is independent of IFN- $\gamma$ (34). The compounds which induce IDO1 expression in DC have been reviewed previously (36). In addition to IDO1 induction, blockade of cyclooxygenase (COX)-2 has been reported to downregulate IDO1 expression in tumors of animal models, suggesting an interplay between these two enzymes (37).

\section{INDOLEAMINE 2,3-DIOXYGENASE-2}

Indoleamine 2,3-dioxygenase-2 (IDO-like protein, INDOL1, proto-IDO) was described first in $2007(38,39)$ and has been reviewed recently (40). IDO2 has a molecular weight of $47 \mathrm{kDa}$, is composed of 420 amino acid residues, and displays $43 \%$ identity with IDO1 at the amino acid level. The gene for IDO2 is located on chromosome 8, adjacent to its paralog IDO1, and may have arisen from gene duplication (41). Alternatively spliced transcripts have been described (42), however, it is unclear whether they are all translated into protein. Two genetic polymorphisms in the human gene encoding IDO2 ablate its enzymatic activity, such that about 
Table 1 | Expression of IDO1 in various types of vascular endothelium.

\begin{tabular}{|c|c|c|c|c|}
\hline Constitutive & $\begin{array}{l}\text { Following inflammation } \\
\text { in vivo }\end{array}$ & $\begin{array}{l}\text { Following cytokine stimulation } \\
\text { (IFN } \gamma \text { and/or TNF- } \alpha \text { or IL-1 } \beta \text { ) }\end{array}$ & $\begin{array}{l}\text { Constitutively negative } \\
\text { expression following cytokine } \\
\text { stimulation not tested }\end{array}$ & $\begin{array}{l}\text { No or little even } \\
\text { after stimulation } \\
\text { with IFN } \gamma\end{array}$ \\
\hline $\begin{array}{l}\text { Chorionic vascular } \\
\text { endothelium }(26,28, \\
\text { 59) }\end{array}$ & $\begin{array}{l}\text { Mouse brain vascular } \\
\text { endothelium }(63,125)\end{array}$ & HUVEC $(28,116)$ & Iliac vein endothelial cells (28) & $\begin{array}{l}\text { HSVEC (IDO } \\
\text { upregulated after } \\
\text { mycoplasma } \\
\text { infection) (116) }\end{array}$ \\
\hline $\begin{array}{l}\text { Arteries and capillaries } \\
\text { of the decidua }(26,28)\end{array}$ & $\begin{array}{l}\text { Mouse microvascular } \\
\text { endothelium in kidney and } \\
\text { intestine during cerebral } \\
\text { malaria infection or after } \\
\text { administration of LPS (63) }\end{array}$ & $\operatorname{HAEC}(10,28)$ & & RAEC (116) \\
\hline $\begin{array}{l}\text { Pulmonary capillaries } \\
\text { (Blaschitz, unpublished } \\
\text { observations), } \\
\text { expression enhanced in } \\
\text { hypoxia (62) }\end{array}$ & $\begin{array}{l}\text { Human microvascular } \\
\text { endothelial cells in heart and } \\
\text { kidney in septic shock (30) }\end{array}$ & $\begin{array}{l}\text { HBMEC (126) } \\
\text { Vascular endothelial cells following } \\
\text { incubation of porcine, rabbit, rat, } \\
\text { and mouse coronary, carotid, and } \\
\text { aortic arteries with IFN- } \gamma(63)\end{array}$ & & IMAEC (116) \\
\hline
\end{tabular}

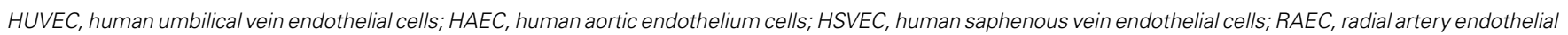
cells; IMAEC, internal mammary artery endothelial cells; HBMEC, human brain microvascular endothelial cells.

$50 \%$ of Caucasians and Asians and $25 \%$ of Africans lack functional IDO2 alleles (42).

Expression of IDO2 mRNA has been described in kidney, liver, epididymis, testis, uterus, placenta, and brain $(15,38,43)$. IDO2 has also been found in sperm tails (38), pancreatic cancer cell lines (44), and tumors of the stomach, colon, and kidney (45). Similar to IDO1, IFN- $\gamma$ upregulates IDO2 expression in DC (45), mesenchymal stem cells, macrophages, and astrocytes (43), although IFN- $\gamma$ does not necessarily induce IDO1 and IDO2 simultaneously (19, 43). Preferential inhibition of IDO2 by a particular 1-MT enantiomer is contentious. An early report of more efficient inhibition by the $\mathrm{D}$-isomer of 1 -MT $(42)$ has not been confirmed $(16,46)$ [for discussion see (40)]. Tenatoprazole has been reported to inhibit IDO2 without affecting IDO1 or TDO, although this compound also displays other biological effects (47).

\section{FURTHER TrP-DEGRADING ENZYMES}

Like IDO1, TDO is a cytosolic heme dioxygenase. It is coded for by the TDO2 gene and displays only $10 \%$ amino acid sequence identity with IDO1 (48). The structure and function of TDO and IDO1 have been compared previously (49). TDO is a homotetramer with a subunit molecular weight of $103 \mathrm{kDa}$. In contrast to IDO1, TDO is enantiomer-specific and only cleaves the $\mathrm{L}$-isoform of Trp (48). Although thought initially to be expressed in the liver only, TDO is also present in placenta (50), brain (51), and a variety of human carcinomas. In the mouse endometrium, TDO is induced at the time of implantation (52). The expression of TDO is upregulated by glucocorticoids $(53,54)$ and by L-Trp (55). 1MT does not inhibit TDO, while the compound 680C91 has been reported to selectively block TDO but not IDO1 (56).

Tryptophan hydroxylases (Tph-1 and Tph-2) convert Trp to 5-hydroxytryptophan for subsequent synthesis of serotonin and melatonin, rather than being involved in the kynurenine pathway.
Tph-1 and Tph-2 are homologous enzymes with $71 \%$ amino acid sequence identity, and with their respective genes located on chromosomes 11 and 12. Mast cells are the major source of Tph-1, whereas Tph-2 is expressed predominantly in neuronal cells of the brain stem (57).

\section{PLACENTAL EXPRESSION AND LOCALIZATION OF Trp-DEGRADING ENZYMES}

There are several, albeit partly conflicting reports on the localization of IDO1 in the human placenta.

\section{ID01 IN THE CHORIONIC VASCULAR ENDOTHELIUM}

In early pregnancy, IDO1 expression is restricted exclusively to immediately subtrophoblastic capillaries (Figure 2), and it increases with advancing gestational age. In term placenta, the endothelium of larger vessels in stem villi and some arteries and veins of the chorionic plate stain positive for IDO1 protein, whereas the vessels of the umbilical cord remain IDO1 negative $(28,58,59)$ (Figure 3). Similar results for chorionic vascular endothelial expression of IDO1 have been described in rhesus monkeys and common marmosets (60). This increase in protein expression correlates with both the amount of mRNA in the placenta and the increase in the placental kynurenine-to-Trp ratio, a surrogate measure of IDO activity. In term placentas at delivery, the kynurenine-to-Trp ratio measured in the blood obtained from vessels of the chorionic plate is far higher than that in the peripheral blood of healthy blood donors (28). This suggests that endothelial IDO1 within placental vessels is highly active beyond the cessation of placental blood circulation at delivery. Consistent with this, endothelial cells isolated from the chorionic plate of term placenta express IDO1 mRNA, in contrast to endothelial cells isolated from human umbilical vein, iliac vein, or aorta (28). Moreover, expression of the aryl hydrocarbon receptor (AhR) 
AhR, a receptor for kynurenine, has been reported for syncytiotrophoblasts, the endothelium of large vessels in the chorionic villi, and in the endothelium of umbilical cord arteries and veins (61).

\section{ID01 IN VASCULAR ENDOTHELIUM OF THE DECIDUA AND THE UTERUS}

In endometrium of non-pregnant women, vascular endothelium does not express IDO1 protein, whereas the protein is expressed in HLA-DR-negative endothelium of spiral arteries and in capillaries. In contrast, the HLA-DR-positive endothelium of veins of the decidua is negative for IDO1 as assessed by immunohistochemistry (Figure 2). During mid-gestation, endothelial expression IDO1 extends to the inner but not the outer layer of the myometrium $(26,28)$. Thus, endothelial IDO1 is increasingly expressed the tissue closer to the feto-maternal interface, similar to the situation in the chorion. It is noticeable that constitutive expression of IDO1 in vascular endothelium is limited to the placenta, the uterus, and the lungs $(28,62)$ (Blaschitz,

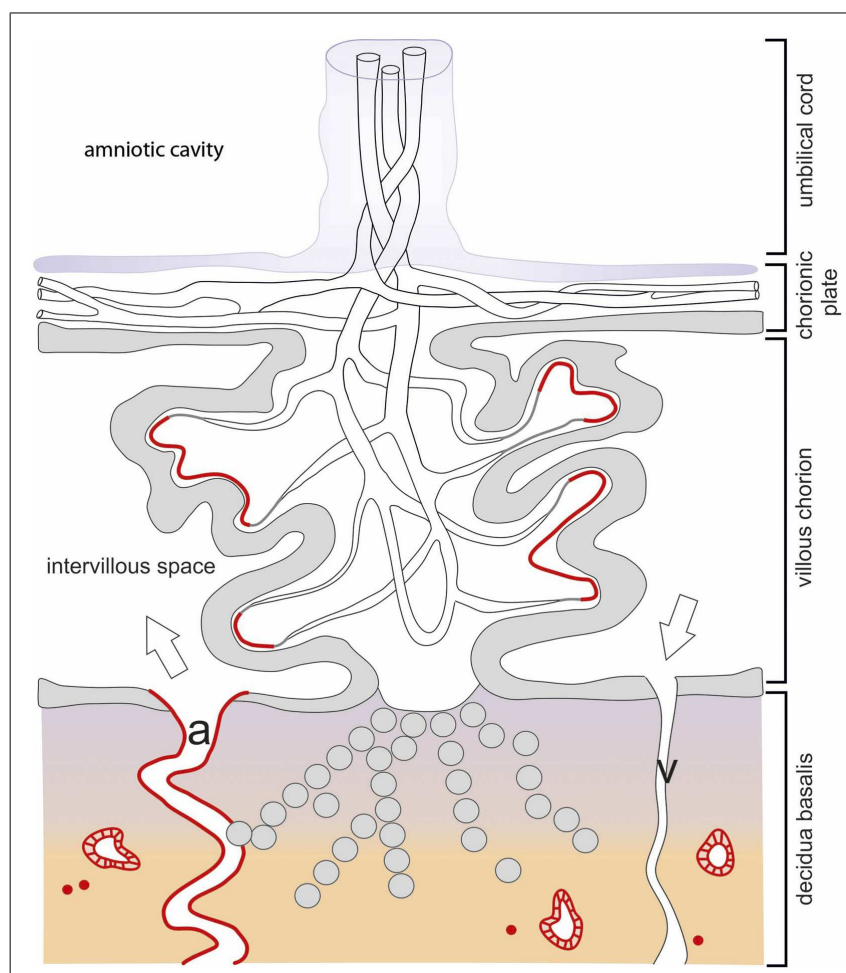

FIGURE 2 | Schematic drawing of the localization of IDO1 in the human placenta during first trimester pregnancy. The chorionic villus is the structural element involved in feto-maternal exchanges. The stem villi originate from the chorionic plate and ramify into villous branches. They consist of a core of mesenchymal connective tissue containing vessels, which are in contact with the fetal vasculature via the umbilical cord. The chorionic villi are covered by a double layer of villous trophoblast (the upper syncytiotrophoblast and the lower cytotrophoblast) separating the fetal closed blood circulation from the intervillous space, which is filled with maternal blood which is supplied via the uterine spiral arteries (a) and discharged via the uterine veins (v). Some of the villi are anchored into the maternal decidua basalis by roots built of extra-villous cytotrophoblast cells, which also invade the maternal decidua. The IDO1 expression sites are highlighted in red color and refer to the villous subtrophoblastic capillaries, few immune cells of the decidua, and the epithelium of uterine glands. unpublished observations). In contrast, IDO1 appears to be more generally expressed in the endothelium under conditions of systemic inflammation (63).

\section{ID01 IN EPITHELIUM OF THE ENDOMETRIUM AND THE DECIDUA}

Expression of IDO1 increases over the course of the menstrual cycle in the surface and glandular epithelium of the endometrium, just as the protein is expressed in cervical glands and epithelium of Fallopian tubes in non-pregnant women. Cervical mucus displays some Trp-degrading activity (26). In first trimester decidua, IDO1 is present in glandular epithelial cells $(26,59)$.

\section{ID01 IN THE TROPHOBLAST}

There is discrepancy among publications as to whether IDO1 is expressed in trophoblast cells. Earlier publications reported IDO1 to be present in first trimester (59) and/or term placenta syncytiotrophoblast $(26,58,64)$ and in extra-villous cytotrophoblast cells $(58,64)$. Hönig et al. described IDO1 in the invasive extravillous trophoblast in the decidua basalis and trophoblast giant cells (58). These observations were challenged in a subsequent publication that also discussed possible reasons for the apparent discrepancies (28). In keeping with this, Wang et al. (65) reported that isolated first trimester trophoblast cells do not constitutively express IDO1 mRNA and protein. However, treatment with polyinosinic-polycytidylic acid [poly(I:C)] (a synthetic

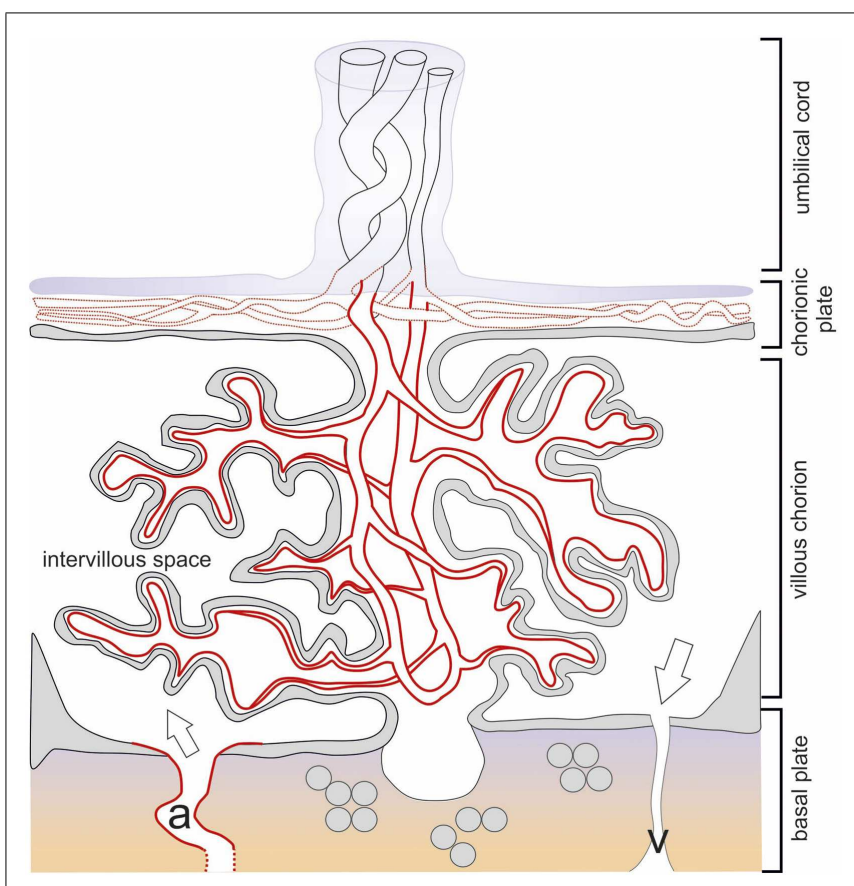

FIGURE 3 | Schematic drawing of the term placenta with the basal plate after delivery. The structures of placental architecture are described in the legend to Figure 1. Here, the branching of the villous tree has increased, the villous trophoblast is largely reduced to the syncytiotrophoblast. IDO1 protein is indicated by red color broken red lines indicate partial expression. All endothelia of the vessels of the villous chorion express IDO1, while only part of the vessels of the chorionic plate and none of the umbilical cord vessels are positive. Openings of maternal arteries (a) express IDO1 whereas veins do not. 
double-stranded RNA, which mimics viral RNA and is a ligand of the Toll-like receptor-3) induced IDO1 mRNA and Trpdegrading activity in the trophoblasts (65). Conditioned media from poly(I:C)-treated trophoblast cells suppresses T cell DNA synthesis, and IFN- $\beta$ was identified as the mediator of this effect via the induction of IDO1 (65). In human placental explants, IDO1 mRNA was found after $24 \mathrm{~h}$ of culture, the expression increased following LPS stimulation (66).

Recently, expression of IDO1 mRNA was described in cultured third trimester human placental cytotrophoblast cells, with higher expression in male than in female CT cells (67). However, these cytotrophoblast preparations also contained CD34 mRNA (Cvitic and Desoye, personal communication), so that contamination with endothelial cells cannot be excluded. Contaminating endothelial cells may also explain similar findings reported earlier by Dong et al. (68). In mice, placental IDO1 expression was found to be limited to trophoblast giant cells (69).

\section{ID01 IN OTHER PLACENTAL CELL TYPES}

Indoleamine 2,3-dioxygenase-1 expression has been reported in macrophages of the villous stroma $(59,64)$. However, this finding was contested subsequently by the observation that IDO1-positive chorionic cells consistently co-expressed CD34 (28), suggesting that in the villous stroma IDO1 is restricted to endothelial cells. IDO1 protein is absent from the majority of macrophages and DC in the decidua $(70,71)$. However, IDO1 can be induced in these cells by treatment with CTLA-4 or IFN- $\gamma$ (71). Decidual macrophages sorted for $\mathrm{CD} 14^{+}$have been reported to express IDO1 mRNA (72), although the purity of these cells was only $72-90 \%$, so that it cannot be ruled out that contaminating cells rather than macrophages were responsible for the observed presence of IDO1 mRNA. Jones et al. implied the presence of IDO1 in mesenchymal stem cells grown from placentae, based on the observation that these cells suppressed allogeneic $\mathrm{T}$ cell proliferation in a manner partly dependent on IDO1 (73). Unpublished data show expression of IDO1 protein in stromal cells of the placental bed post partum (Astrid Blaschitz).

\section{TDO AND ID02}

Limited information is available regarding the localization and role of TDO in the placenta. TDO mRNA and protein has been observed in mouse concept and placenta at a time preceding IDO1 expression (50). Dharane et al. reported TDO mRNA to be present in human placental explants (prepared following caesarian section) after $24 \mathrm{~h}$ of culture, and its expression increased following ex vivo exposure to LPS (66).

Indoleamine 2,3-dioxygenase- 2 mRNA has been detected in term and, to a much lower extent, also in first trimester placentae (74). Isolated first trimester and term trophoblast cells as well as the BeWo choriocarcinoma cell line do not express IDO2 mRNA (74). Preliminary observations suggest, however, that both IDO2 and TDO protein are expressed in the human placenta (Astrid Blaschitz, unpublished data).

\section{FURTHER ENZYMES INVOLVED IN Trp DEGRADATION}

Kynurenine 3-hydroxylase (KYN-OHase) catalyzes the oxidation of kynurenine to 3-hydroxykynurenine. KYN-OHase has been localized to glandular epithelial cells of first trimester decidua, as well as the syncytiotrophoblast, stroma, and macrophages of first trimester placenta. In term placenta, KYN-OHase expression was confined mainly to vascular endothelial cells of villous blood vessels, and to macrophages within the fetal villus (59). We are aware of only a single report of Tph (is it Tph-1?) in the cytoplasm of human cytotrophoblasts and syncytiotrophoblasts (75).

\section{ROLE OF Trp DEGRADATION GENERAL ASPECTS}

It has been known for decades that IDO1 is induced during infections and displays antimicrobial activity. Originally, induction of IDO has been observed in the lung following application of bacterial LPS (76) and infection with influenza virus (77). Such infection-associated induction of IDO1 was soon found to be mediated by IFN- $\gamma$ (78). In a variety of different human cell lines, induction of IDO1 by IFN- $\gamma$ is associated with growth inhibition of intracellular bacteria (such as Chlamydia psittaci) and protozoa (Toxoplasma gondii), as well an extracellular bacteria $(14,79,80)$. In many though not all situations, addition of exogenous L-Trp attenuates growth inhibition, consistent with the notion that limitation of this essential amino acid by IDO1 at least in part explains the antimicrobial activity observed. The antimicrobial activity of IDO1 in human endothelial cells has been reviewed recently (81).

Oxidative degradation of Trp leads to both, a local depletion of Trp and formation of Trp metabolites. Both aspects are biologically relevant and have recently been reviewed (82), see also Table 2. For example, the Trp metabolites kynurenine (83) and kynurenic acid (84) are ligands of the AhR. Following ligand binding, this cytosolic transcription factor translocates into the nucleus where it binds to response elements in the promoters of target genes (85). In this way, kynurenine displays immunosuppressive properties by generating regulatory $\mathrm{T}\left(\mathrm{T}_{\mathrm{reg}}\right)$ cells $(86)$. The immunogenicity of DC is decreased, as AhR signaling induces DC to express IDO1 and IL10 (86-89). 3-Hydroxyanthranilic acid (3-HAA) as well as the other kynurenine metabolites anthranilic acid, quinolinic acid, and nicotinamide do not directly activate the AhR. Hydroxykynurenine does display an effect which, however, is weaker than kynurenine (86). On the other hand, 3-HAA has been suggested to prime DC for expressing reduced levels of pro-inflammatory cytokines, enhanced levels of TGF- $\beta$, and inducing $\mathrm{T}_{\text {reg }}$ cells (90, 91). The depletion of Trp also triggers amino-acid-sensing signal transduction pathways, such as the GCN2 kinase and inhibition of mTOR (92). The former pathway leads to cell-cycle arrest and functional anergy in $\mathrm{CD}^{+} \mathrm{T}$ cells (93). Lymphocytes are specifically affected by Trp depletion. This is because in these cells, IFN- $\gamma$ does not induce tryptophanyl-tRNA synthetase so that lymphocytes are inefficient in competing for Trp compared with other cells $(94,95)$. In T helper cells, Trp depletion inhibits differentiation to $\mathrm{Th}_{17}$ cells (96) and it promotes de novo $\mathrm{T}_{\text {reg }}$ differentiation (97). IFN- $\gamma$ is the main inducer of IDO in DC for the prevention of hyperinflammatory responses, whereas TGF- $\beta$ confers regulatory effects on IDO independent of its enzymatic activity. In this case, IDO1 appears to act as a signaling molecule, by promoting complex formation of IDO1 with the tyrosine protein phosphatases SHP-1 and SHP-2. This leads to long-term tolerance via activation of SHP-1 phosphatase activity in plasmacytoid DC (98). Moreover, 
Table 2 | Pathways of immunomodulation by IDO1 and kynurenine pathway metabolites.

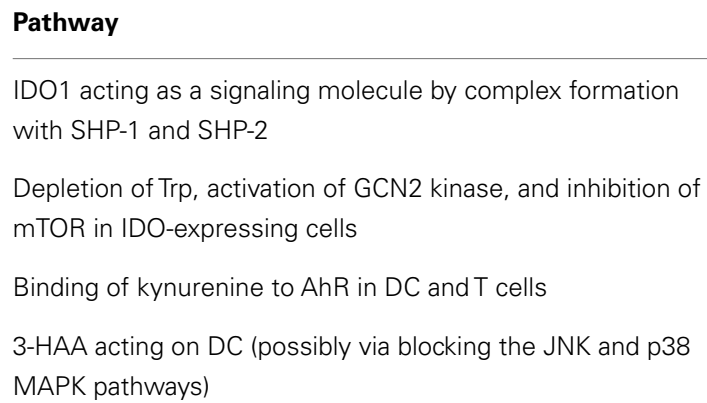

IDO1 plays an important role in the self-limitation of the immune response. Thus, short-term $(4 \mathrm{~h})$ activation of DC with IFN- $\gamma$ and LPS leads to the induction of pro-inflammatory cytokines, while long-term $(48 \mathrm{~h})$ activation favors immunosuppression and tolerance via IDO1 signals $(36,82)$.

As stated above, on one hand IDO1 generates metabolic products that induce $\mathrm{T}_{\text {reg }}$ cells, on the other hand $\mathrm{T}_{\text {reg }}$ cells can induce IDO1 expression (31). This suggests the presence of a positive feedback loop and raises the question of the limitation of this mutual interaction.

Indoleamine 2,3-dioxygenase-1-based suppression of immune reactions against foreign $\mathrm{MHC}-\mathrm{I}$ molecules and minor histocompatibility antigens mediates feto-maternal tolerance $(99,100)$ also via induction of $\mathrm{T}_{\text {reg }}$ cells, which play a critical role in suppressing the anti-fetal immune response (101). The role for this in pregnancy has been questioned based on the fact that matings of allogeneic male and female $\mathrm{IDO}^{-1-}$ mice yield viable offsprings (69). However, IDO2 and/or TDO may compensate for IDO1 and promote Trp metabolism in these mice, particularly as it is increasingly recognized that TDO expression is not limited to the liver. Rather, the enzyme is also present in mouse placenta (50).

Indoleamine 2,3-dioxygenase-1 mediates tolerance against tumors (102), and IDO inhibitors are being tested in clinical trials with patients suffering from cancer and chronic infections (103). Whereas IDO1 has been found in DC of tumor-draining lymph nodes (24), IDO1 could not be detected in regional lymph nodes of uteri of pregnant mice (P. Ack, Astrid Blaschitz, unpublished observations).

Trp metabolites also display non-immunological functions: for example, quinolinic acid and kynurenic acid have neuroactive properties (104-106), and 3-hydroxykynurenine and 3-hydroxyanthranilic acid display antioxidant activity (107). IDO1-mediated degradation of Trp in the endothelium of mice infected with malaria parasites or induced by endotoxemia contributes to the relaxation of arteries and to the control of blood pressure (63). Originally, kynurenine was reported to mediate arterial relaxation under these pro-inflammatory conditions, in part via activation of soluble guanylate cyclase. These findings were based on studies with commercial preparations of kynurenine (63). However, more recently, HPLCpurified kynurenine was found to be inactive, and IDO1-mediated vasorelaxation has been attributed to a yet to be identified Trp metabolite (Proceedings of the British Pharmacological
Society at http://www.pa2online.org/abstract/abstract.jsp?abid। protect $\mid$ kern $+.1667 \mathrm{em} \backslash$ relax $=\mid$ protect $\mid$ kern $+.1667 \mathrm{em} \backslash$ relax31322). Most recently, IDO1 has been reported to mediate angiotensin II-induced production of reactive oxygen species, apoptosis, and endothelial dysfunction (108).

The biological role of IDO2 is as yet unclear. Its Trp-degrading activity is much lower or even undetectable (15) compared with IDO1 (41), at least in the in vitro ascorbate/methylene blue assay commonly used (14). However, the probable physiological electron donor cytochrome $b_{5}$ reduces recombinant mouse IDO 2 and it increases its activity in vitro compared with that observed in the ascorbate/methylene blue assay (16). Human IDO2 expression is not able to rescue a yeast strain auxotrophic for nicotinic acid, suggesting it does not have sufficient activity to supply $\mathrm{NAD}^{+}$in yeast (109). On the other hand, chemokine-induced production of kynurenine in human basal carcinoma cells correlated with the induction of mRNA expression of IDO2, but not IDO1 (110). It has been suggested that IDO2 activity is determined by the presence of particular co-factors that may be present only in certain cell types or conditions (40).

The high expression of TDO in the liver (111) makes it the key enzyme regulating circulating concentrations of $\mathrm{L}$-Trp, and it is believed to have a major role in supplying $\mathrm{NAD}^{+}(112)$. $\mathrm{TDO}^{-1-}$ mice display increased plasma concentrations of Trp, leading to increased serotonin biosynthesis and alterations in behavior and neurogenesis (113). In analogy to IDO1, TDO activity also has been implicated in the inhibition of immune responses against tumors (56).

Hydroxylation by Tph-1 may also contribute to the exhaustion of Trp in a microenvironment, and it too has immunoregulatory effects. Tph-1 deficiency breaks allograft tolerance, induces tumor remission, and intensifies neuroinflammation. These effects are independent of the downstream product serotonin (114).

\section{FUNCTIONAL ASPECTS OF PLACENTAL Trp CATABOLISM}

Localization of IDO1 in the utero-placental unit leaves us to speculate about its role at this site in particular: IDO1 in the epithelium of the mucosal surface and the glands of the endometrium and the decidua, and secretion of IDO [reflected in Trp-degrading activity in the cervical mucus (26)) may provide a mechanism of innate immunity against ascending infections of the female reproductive tract with intracellular bacteria such as Chlamydia but also against extracellular pathogens. 
Endothelial cells may act as semi-professional antigenpresenting cells (115) and, as they degrade Trp, may contribute to the suppression of the immune response (31). Inhibition of IDO activity improves the ability of human umbilical vein endothelial cells to stimulate allogeneic T-cell responses. Transfection of these cells or human saphenous vein endothelial cells with the IDO1 gene, stimulates allogeneic T-cell responses and induces anergy in allospecific $\mathrm{T}$ cells (116). IDO1-positive endothelial cells of both the fetal and the maternal part of the placenta do not coexpress HLA-DR, which renders their contribution to the establishment and maintenance of feto-maternal tolerance unlikely. In situations where pro-inflammatory stimuli act on and induce MHC-II expression in placental endothelial cells, the ensuing immune response may, however, be modulated by endothelial IDO1. An antibacterial and antiparasitic role of endothelial IDO1 may be anticipated, and this might contribute to protection of the feto-placental unit against infection (81).

Endothelial catabolism of Trp by IDO1 in the villous chorion may also contribute to the regulation of the placental vasotonus. Preliminary data suggest that preconstriced human placental arterial rings relax in response to added Trp, and that this relaxation is partly inhibited by 1-MT (Roland Stocker, Peter Sedlmayr, unpublished observations). As the maintenance of placental perfusion is of crucial importance to the fetus, IDO1-induced relaxation of placental vessels may play an important role for feto-placental growth in the course of pregnancy. Moreover, on the other side of the interface, expression of IDO1 in the endothelium of spiral arteries may induce vasodilation and contribute to feeding blood into the intervillous space. This suggested role of IDO1 at this location might be a phenomenon particularly relevant after the first trimester of pregnancy, once the endovascular trophoblast plugs have vanished.

\section{ALTERED TrP DEGRADATION IN PREGNANCY PATHOLOGY}

There are reports of reduced placental IDO1 mRNA, protein, and placental Trp-degrading activity in preeclampsia, including a correlation between reduced placental Trp-degrading activity and the severity of the disease $(27,117-119)$. Not all studies, however, take into account that the gestational age of preeclamptic placentae needs to be matched to control placentae, as placental IDO1 expression normally increases with gestational age. Whereas the kynurenine-to-Trp ratio in plasma increases during normal pregnancy, in preeclampsia it remains unchanged and similar to that in non-pregnant women $(117,120)$.

In a model of pregnant mice carrying hemiallogeneic concept, pharmacological inhibition of IDO1 was reported to result in the mothers developing high blood pressure, proteinuria, and impairment of the local placental circulation, analogous to the lesions characteristic of human preeclampsia (121). In this model, 8-hydroxy-2'-deoxy-guanosine (8-OHdG, a marker for oxidative damage to DNA) was found to be higher in preeclamptic than normotensive pregnancies. Moreover, immunohistochemical signals of 8-OHdG inversely correlated with Trp-degrading activity, suggesting that a decrease in the antioxidant activity of IDO1 contributed to the pathogenesis of this disorder (122).

So far, little is known regarding the role of IDO1 in the context of intrauterine growth restriction (IUGR, synonymous with fetal growth restriction). There is one (however not in-depth) report stating that placentae in this disease show decreased IDO activity (123). Current interest focuses on a possible pathogenetic role of endothelial IDO1: in IUGR with and without preeclampsia chorionic vessels show reduced expression of IDO1, as assessed by immunohistochemistry, and a decrease in the relaxation of placental arteries induced ex vivo by added Trp (Roland Stocker and co-workers, unpublished).

Indoleamine 2,3-dioxygenase-1 expression in monocytes, macrophages, and DC of the decidua and of peripheral blood increases in normal pregnancy after treatment with CTLA-4 or IFN- $\gamma$ whereas it decreases in spontaneous abortion (71). In allogeneic pregnancies in mice, application of 1-MT leads to $\mathrm{T}$ cell-mediated hemorrhagic necrosis and rejection of the conceptus soon after implantation $(99,100)$. This situation is similar to that of in vivo administration of an antibody against the $\mathrm{T}$ cell receptor $\beta$ chain (124), and may be analogous to early pregnancy loss in humans, also called "chemical pregnancies."

\section{CONCLUSION}

Trp-degrading enzymes in the placenta lead to a deprivation of tryptophan and the formation of biologically active tryptophan metabolites at and near the sites of catabolism. The combination of these two processes has important consequences for the establishment and maintenance of feto-maternal immune tolerance. In addition, it may affect placental circulation and growth, as well as modulate local antimicrobial activity, the precise underlying mechanisms of which await elucidation. In particular, at present we lack detailed information on the expression, localization, and specific roles of IDO2 and TDO in the placenta. The occurrence of allogeneic pregnancies in $\mathrm{IDO}^{-1-}$ mice suggests redundancy for the role of IDO1 in protecting against alloreactive maternal $\mathrm{T}$ cells, the mechanism of which needs to be uncovered. This might be done, e.g., by using various combinations of IDO1, IDO2, and TDO double gene knockout mice, perhaps in combination with pharmacological inhibition of the third Trp-oxidizing enzyme where appropriate.

\section{ACKNOWLEDGMENTS}

This work was supported by Project Grant 1020400 and a Senior Principal Research Fellowship from the National Health and Medical Research Council of Australia (to Roland Stocker) and by funds of the Oesterreichische National Bank (Anniversary Fund, project number: 15671, to Peter Sedlmayr).

\section{REFERENCES}

1. Food and Nutrition Board. (1974). Recommended Dietary Allowances, 8th ed. Washington DC: National Academy of Sciences.

2. Ikeda M, Tsuji H, Nakamura S, Ichiyama A, Nishizuka Y, Hayaishi O. Studies on the biosynthesis of nicotinamide adenine dinucleotide. Ii. A role of picolinic carboxylase in the biosynthesis of nicotinamide adenine dinucleotide from tryptophan in mammals. J Biol Chem (1965) 240:1395-401.

3. Takikawa O. Biochemical and medical aspects of the indoleamine 2,3dioxygenase-initiated L-tryptophan metabolism. Biochem Biophys Res Commun (2005) 338:12-9. doi:10.1016/j.bbrc.2005.09.032

4. Suzuki T, Kawamichi H, Imai K. A myoglobin evolved from indoleamine 2,3-dioxygenase, a tryptophan-degrading enzyme. Comp Biochem Physiol B Biochem Mol Biol (1998) 121:117-28. doi:10.1016/S0305-0491(98)10086-X 
5. Suzuki T, Yuasa H, Imai K. Convergent evolution. The gene structure of Sulculus $41 \mathrm{kDa}$ myoglobin is homologous with that of human indoleamine dioxygenase. Biochim Biophys Acta (1996) 1308:41-8. doi:10.1016/0167-4781(96) 00059-0

6. Dai W, Gupta SL. Molecular cloning, sequencing and expression of human interferon-gamma-inducible indoleamine 2,3-dioxygenase cDNA. Biochem Biophys Res Commun (1990) 168:1-8. doi:10.1016/0006-291X(90)91666-G

7. Tone S, Takikawa O, Habara Ohkubo A, Kadoya A, Yoshida R, Kido R. Primary structure of human indoleamine 2,3-dioxygenase deduced from the nucleotide sequence of its cDNA. Nucleic Acids Res (1990) 18:367. doi:10.1093/ nar/18.2.367

8. Maezono K, Tashiro K, Nakamura T. Deduced primary structure of rat tryptophan-2,3-dioxygenase. Biochem Biophys Res Commun (1990) 170:176-81. doi:10.1016/0006-291X(90)91256-R

9. Taniguchi T, Hirata F, Hayaishi O. Intracellular utilization of superoxide anion by indoleamine 2,3-dioxygenase of rabbit enterocytes. J Biol Chem (1977) 252:2774-6.

10. Maghzal GJ, Thomas SR, Hunt NH, Stocker R. Cytochrome b5, not superoxide anion radical, is a major reductant of indoleamine 2,3-dioxygenase in human cells. J Biol Chem (2008) 283:12014-25. doi:10.1074/jbc.M710266200

11. Basran J, Efimov I, Chauhan N, Thackray SJ, Krupa JL, Eaton G, et al. The mechanism of formation of $\mathrm{N}$-formylkynurenine by heme dioxygenases. $\mathrm{JAm}$ Chem Soc (2011) 133:16251-7. doi:10.1021/ja207066z

12. Taniguchi T, Sono M, Hirata F, Hayaishi O, Tamura M, Hayashi K, et al. Indoleamine 2,3-dioxygenase. Kinetic studies on the binding of superoxide anion and molecular oxygen to enzyme. J Biol Chem (1979) 254:3288-94.

13. Freewan M, Rees MD, Plaza TS, Glaros E, Lim YJ, Wang XS, et al. Human indoleamine 2,3-dioxygenase is a catalyst of physiological heme peroxidase reactions: implications for the inhibition of dioxygenase activity by hydrogen peroxide. J Biol Chem (2013) 288:1548-67. doi:10.1074/jbc.M112.410993

14. Takikawa O, Kuroiwa T, Yamazaki F, Kido R. Mechanism of interferongamma action. Characterization of indoleamine 2,3-dioxygenase in cultured human cells induced by interferon-gamma and evaluation of the enzymemediated tryptophan degradation in its anticellular activity. J Biol Chem (1988) 263:2041-8.

15. Löb S, Königsrainer A, Schafer R, Rammensee HG, Opelz G, Terness P. Levobut not dextro-1-methyl tryptophan abrogates the IDO activity of human dendritic cells. Blood (2008) 111:2152-4. doi:10.1182/blood-2007-10-116111

16. Austin CJ, Mailu BM, Maghzal GJ, Sanchez-Perez A, Rahlfs S, Zocher K, et al. Biochemical characteristics and inhibitor selectivity of mouse indoleamine 2,3-dioxygenase-2. Amino Acids (2010) 39:565-78. doi:10.1007/s00726-0100475-9

17. Chauhan N, Thackray SJ, Rafice SA, Eaton G, Lee M, Efimov I, et al. Reassessment of the reaction mechanism in the heme dioxygenases. J Am Chem Soc (2009) 131:4186-7. doi:10.1021/ja808326g

18. Macchiarulo A, Camaioni E, Nuti R, Pellicciari R. Highlights at the gate of tryptophan catabolism: a review on the mechanisms of activation and regulation of indoleamine 2,3-dioxygenase (IDO), a novel target in cancer disease. Amino Acids (2009) 37:219-29. doi:10.1007/s00726-008-0137-3

19. Liu X, Shin N, Koblish HK, Yang G, Wang Q, Wang K, et al. Selective inhibition of IDO1 effectively regulates mediators of antitumor immunity. Blood (2010) 115:3520-30. doi:10.1182/blood-2009-09-246124

20. Meininger D, Zalameda L, Liu Y, Stepan LP, Borges L, Mccarter JD, et al. Purification and kinetic characterization of human indoleamine 2,3-dioxygenases 1 and 2 (IDO1 and IDO2) and discovery of selective IDO1 inhibitors. Biochim Biophys Acta (2011) 1814:1947-54. doi:10.1016/j.bbapap.2011.07.023

21. Yamazaki F, Kuroiwa T, Takikawa O, Kido R. Human indolylamine 2,3dioxygenase. Its tissue distribution, and characterization of the placental enzyme. Biochem J (1985) 230:635-8.

22. Jrad-Lamine A, Henry-Berger J, Gourbeyre P, Damon-Soubeyrand C, Lenoir A, Combaret L, et al. Deficient tryptophan catabolism along the kynurenine pathway reveals that the epididymis is in a unique tolerogenic state. J Biol Chem (2011) 286:8030-42. doi:10.1074/jbc.M110.172114

23. Onodera T, Jang MH, Guo Z, Yamasaki M, Hirata T, Bai Z, et al. Constitutive expression of IDO by dendritic cells of mesenteric lymph nodes: functional involvement of the CTLA-4/B7 and CCL22/CCR4 interactions. J Immunol (2009) 183:5608-14. doi:10.4049/jimmunol.0804116
24. Munn DH, Sharma MD, Hou D, Baban B, Lee JR, Antonia SJ, et al. Expression of indoleamine 2,3-dioxygenase by plasmacytoid dendritic cells in tumordraining lymph nodes. J Clin Invest (2004) 114:280-90. doi:10.1172/JCI21583

25. Odemuyiwa SO, Ghahary A, Li Y, Puttagunta L, Lee JE, Musat-Marcu S, et al. Cutting edge: human eosinophils regulate $\mathrm{T}$ cell subset selection through indoleamine 2,3-dioxygenase. J Immunol (2004) 173:5909-13. doi:10.4049/ jimmunol.173.10.5909

26. Sedlmayr P, Blaschitz A, Wintersteiger R, Semlitsch M, Hammer A, Mackenzie $\mathrm{CR}$, et al. Localization of indoleamine 2,3-dioxygenase in human female reproductive organs and the placenta. Mol Hum Reprod (2002) 8:385-91. doi:10.1093/molehr/8.4.385

27. Santoso DIS, Rogers P, Wallace EM, Manuelpillai U, Walker D, Subakir SB. Localization of indoleamine 2,3-dioxygenase and 4-hydroxynonenal in normal and pre-eclamptic placentae. Placenta (2002) 23:373-9. doi:10.1053/plac. 2002.0818

28. Blaschitz A, Gauster M, Fuchs D, Lang I, Maschke P, Ulrich D, et al. Vascular endothelial expression of indoleamine 2,3-dioxygenase 1 forms a positive gradient towards the feto-maternal interface. PLoS One (2011) 6:e21774. doi:10.1371/journal.pone.0021774

29. Riesenberg R, Weiler C, Spring O, Eder M, Buchner A, Popp T, et al. Expression of indoleamine 2,3-dioxygenase in tumor endothelial cells correlates with long-term survival of patients with renal cell carcinoma. Clin Cancer Res (2007) 13:6993-7002. doi:10.1158/1078-0432.CCR-07-0942

30. Changsirivathanathamrong D, Wang Y, Rajbhandari D, Maghzal GJ, Mak WM, Woolfe C, et al. Tryptophan metabolism to kynurenine is a potential novel contributor to hypotension in human sepsis. Crit Care Med (2011) 39:2678-83. doi:10.1097/CCM.0b013e31822827f2

31. Thebault P, Condamine T, Heslan M, Hill M, Bernard I, Saoudi A, et al. Role of IFNgamma in allograft tolerance mediated by CD4+CD25+ regulatory T cells by induction of IDO in endothelial cells. Am J Transplant (2007) 7:2472-82. doi:10.1111/j.1600-6143.2007.01960.x

32. Xiao BG, Liu X, Link H. Antigen-specific T cell functions are suppressed over the estrogen-dendritic cell-indoleamine 2,3-dioxygenase axis. Steroids (2004) 69:653-9. doi:10.1016/j.steroids.2004.05.019

33. Steckel NK, Koldehoff M, Beelen DW, Elmaagacli AH. Indoleamine 2,3dioxygenase expression in monocytes of healthy nonpregnant women after induction with human choriongonadotropine. Scand J Immunol (2005) 61:213-4. doi:10.1111/j.0300-9475.2005.01538.x

34. Ueno A, Cho S, Cheng L, Wang J, Hou S, Nakano H, et al. Transient upregulation of indoleamine 2,3-dioxygenase in dendritic cells by human chorionic gonadotropin downregulates autoimmune diabetes. Diabetes (2007) 56:1686-93. doi:10.2337/db06-1727

35. Wan H, Versnel MA, Leijten LM, Van Helden-Meeuwsen CG, Fekkes D, Leenen PJ, et al. Chorionic gonadotropin induces dendritic cells to express a tolerogenic phenotype. J Leukoc Biol (2008) 83:894-901. doi:10.1189/jlb.0407258

36. Heitger A. Regulation of expression and function of IDO in human dendritic cells. Curr Med Chem (2011) 18:2222-33. doi:10.2174/092986711795656018

37. Cesario A, Rocca B, Rutella S. The interplay between indoleamine 2,3dioxygenase 1 (IDO1) and cyclooxygenase (COX)-2 in chronic inflammation and cancer. Curr Med Chem (2011) 18:2263-71. doi:10.2174/ 092986711795656063

38. Ball HJ, Sanchez-Perez A, Weiser S, Austin CJ, Astelbauer F, Miu J, et al. Characterization of an indoleamine 2,3-dioxygenase-like protein found in humans and mice. Gene (2007) 396:203-13. doi:10.1016/j.gene.2007.04.010

39. Murray MF. The human indoleamine 2,3-dioxygenase gene and related human genes. Curr Drug Metab (2007) 8:197-200. doi:10.2174/138920007780362509

40. Fatokun AA, Hunt NH, Ball HJ. Indoleamine 2,3-dioxygenase 2 (IDO2) and the kynurenine pathway: characteristics and potential roles in health and disease. Amino Acids (2013) 45:1319-29. doi:10.1007/s00726-013-1602-1

41. Yuasa HJ, Takubo M, Takahashi A, Hasegawa T, Noma H, Suzuki T. Evolution of vertebrate indoleamine 2,3-dioxygenases. J Mol Evol (2007) 65:705-14. doi:10.1007/s00239-007-9049-1

42. Metz R, Duhadaway JB, Kamasani U, Laury-Kleintop L, Muller AJ, Prendergast GC. Novel tryptophan catabolic enzyme IDO2 is the preferred biochemical target of the antitumor indoleamine 2,3-dioxygenase inhibitory compound D1-methyl-tryptophan. Cancer Res (2007) 67:7082-7. doi:10.1158/0008-5472. CAN-07- 1872 
43. Croitoru-Lamoury J, Lamoury FM, Caristo M, Suzuki K, Walker D, Takikawa $\mathrm{O}$, et al. Interferon-gamma regulates the proliferation and differentiation of mesenchymal stem cells via activation of indoleamine 2,3 dioxygenase (IDO). PLoS One (2011) 6:e14698. doi:10.1371/journal.pone.0014698

44. Witkiewicz AK, Costantino CL, Metz R, Muller AJ, Prendergast GC, Yeo CJ, et al. Genotyping and expression analysis of IDO2 in human pancreatic cancer: a novel, active target. J Am Coll Surg (2009) 208:781-7. doi:10.1016/j. jamcollsurg.2008.12.018; discussion 787-789,

45. Löb S, Königsrainer A, Zieker D, Brucher BL, Rammensee HG, Opelz G, et al. IDO1 and IDO2 are expressed in human tumors: levo- but not dextro-1-methyl tryptophan inhibits tryptophan catabolism. Cancer Immunol Immunother (2009) 58:153-7. doi:10.1007/s00262-008-0513-6

46. Hou DY, Muller AJ, Sharma MD, Duhadaway J, Banerjee T, Johnson M, et al. Inhibition of indoleamine 2,3-dioxygenase in dendritic cells by stereoisomers of 1-methyl-tryptophan correlates with antitumor responses. Cancer Res (2007) 67:792-801. doi:10.1158/0008-5472.CAN-06-2925

47. Bakmiwewa SM, Fatokun AA, Tran A, Payne RJ, Hunt NH, Ball HJ. Identification of selective inhibitors of indoleamine 2,3-dioxygenase 2. Bioorg Med Chem Lett (2012) 22:7641-6. doi:10.1016/j.bmcl.2012.10.010

48. Forouhar F, Anderson JL, Mowat CG, Vorobiev SM, Hussain A, Abashidze M, et al. Molecular insights into substrate recognition and catalysis by tryptophan 2,3-dioxygenase. Proc Natl Acad Sci U S A (2007) 104:473-8. doi:10.1073/pnas. 0610007104

49. Rafice SA, Chauhan N, Efimov I, Basran J, Raven EL. Oxidation of Ltryptophan in biology: a comparison between tryptophan 2,3-dioxygenase and indoleamine 2,3-dioxygenase. Biochem Soc Trans (2009) 37:408-12. doi:10.1042/BST0370408

50. Suzuki S, Tone S, Takikawa O, Kubo T, Kohno I, Minatogawa Y. Expression of indoleamine 2,3-dioxygenase and tryptophan 2,3-dioxygenase in early concepti. Biochem J (2001) 355:425-9. doi:10.1042/0264-6021:3550425

51. Haber R, Bessette D, Hulihan-Giblin B, Durcan MJ, Goldman D. Identification of tryptophan 2,3-dioxygenase RNA in rodent brain. J Neurochem (1993) 60:1159-62. doi:10.1111/j.1471-4159.1993.tb03269.x

52. Tatsumi K, Higuchi T, Fujiwara H, Nakayama T, Egawa H, Itoh K, et al. Induction of tryptophan 2,3-dioxygenase in the mouse endometrium during implantation. Biochem Biophys Res Commun (2000) 274:166-70. doi:10.1006/bbrc. 2000.3115

53. Danesch U, Hashimoto S, Renkawitz R, Schutz G. Transcriptional regulation of the tryptophan oxygenase gene in rat liver by glucocorticoids. J Biol Chem (1983) 258:4750-3.

54. Danesch U, Gloss B, Schmid W, Schutz G, Schule R, Renkawitz R. Glucocorticoid induction of the rat tryptophan oxygenase gene is mediated by two widely separated glucocorticoid-responsive elements. EMBO J (1987) 6:625-30.

55. Knox WE. The regulation of tryptophan pyrrolase activity by tryptophan. $A d v$ Enzyme Regul (1966) 4:287-97. doi:10.1016/0065-2571(66)90023-9

56. Pilotte L, Larrieu P, Stroobant V, Colau D, Dolusic E, Frederick R, et al. Reversal of tumoral immune resistance by inhibition of tryptophan 2,3-dioxygenase. Proc Natl Acad Sci U S A (2012) 109:2497-502. doi:10.1073/pnas.1113873109

57. Walther DJ, Peter JU, Bashammakh S, Hortnagl H, Voits M, Fink H, et al. Synthesis of serotonin by a second tryptophan hydroxylase isoform. Science (2003) 299:76. doi:10.1126/science.1078197

58. Hönig A, Rieger L, Kapp M, Sutterlin M, Dietl J, Kämmerer U. Indoleamine 2,3-dioxygenase (IDO) expression in invasive extravillous trophoblast supports role of the enzyme for materno-fetal tolerance. J Reprod Immunol (2004) 61:79-86. doi:10.1016/j.jri.2003.11.002

59. Ligam P, Manuelpillai U, Wallace EM, Walker D. Localisation of indoleamine 2,3-dioxygenase and kynurenine hydroxylase in the human placenta and decidua: implications for role of the kynurenine pathway in pregnancy. Placenta (2005) 26:498-504. doi:10.1016/j.placenta.2004.08.009

60. Drenzek JG, Breburda EE, Burleigh DW, Bondarenko GI, Grendell RL, Golos TG. Expression of indoleamine 2,3-dioxygenase in the rhesus monkey and common marmoset. J Reprod Immunol (2008) 78:125-33. doi:10.1016/j.jri. 2008.03.005

61. Jiang YZ, Wang K, Fang R, Zheng J. Expression of aryl hydrocarbon receptor in human placentas and fetal tissues. J Histochem Cytochem (2010) 58:679-85. doi:10.1369/jhc.2010.955955

62. Xiao Y, Christou H, Liu L, Visner G, Mitsialis SA, Kourembanas S, et al. Endothelial indoleamine 2,3-dioxygenase protects against development of pulmonary hypertension. Am J Respir Crit Care Med (2013) 188:482-91. doi:10.1164/rccm.201304-0700OC

63. Wang Y, Liu H, Mckenzie G, Witting PK, Stasch JP, Hahn M, et al. Kynurenine is an endothelium-derived relaxing factor produced during inflammation. Nat Med (2010) 16:279-85. doi:10.1038/nm.2092

64. Kudo Y, Boyd CA, Spyropoulou I, Redman CW, Takikawa O, Katsuki T, et al. Indoleamine 2,3-dioxygenase: distribution and function in the developing human placenta. J Reprod Immunol (2004) 61:87-98. doi:10.1016/j.jri.2003. 11.004

65. Wang B, Koga K, Osuga Y, Cardenas I, Izumi G, Takamura M, et al. Tolllike receptor-3 ligation-induced indoleamine 2, 3-dioxygenase expression in human trophoblasts. Endocrinology (2011) 152:4984-92. doi:10.1210/en.20110278

66. Dharane P, Manuelpillai U, Wallace E, Walker DW. NF kappa B-dependent increase of kynurenine pathway activity in human placenta: inhibition by sulfasalazine. Placenta (2010) 31:997-1002. doi:10.1016/j.placenta.2010.09.002

67. Cvitic S, Longtine MS, Hackl H, Wagner K, Nelson MD, Desoye G, et al. The human placental sexome differs between trophoblast epithelium and villous vessel endothelium. PLoS One (2013) 8:e79233. doi:10.1371/journal.pone. 0079233

68. Dong M, Ding G, Zhou J, Wang H, Zhao Y, Huang H. The effect of trophoblasts on T lymphocytes: possible regulatory effector molecules - a proteomic analysis. Cell Physiol Biochem (2008) 21:463-72. doi:10.1159/000129639

69. Baban B, Chandler P, Mccool D, Marshall B, Munn DH, Mellor AL. Indoleamine 2,3-dioxygenase expression is restricted to fetal trophoblast giant cells during murine gestation and is maternal genome specific. J Reprod Immunol (2004) 61:67-77. doi:10.1016/j.jri.2003.11.003

70. Cupurdija K, Azzola D, Hainz U, Gratchev A, Heitger A, Takikawa O, et al. Macrophages of human first trimester decidua express markers associated to alternative activation. Am J Reprod Immunol (2004) 51:117-22. doi:10.1046/j. 8755-8920.2003.00128.x

71. Miwa N, Hayakawa S, Miyazaki S, Myojo S, Sasaki Y, Sakai M, et al. IDO expression on decidual and peripheral blood dendritic cells and monocytes/macrophages after treatment with CTLA- 4 or interferon-gamma increase in normal pregnancy but decrease in spontaneous abortion. Mol Hum Reprod (2005) 11:865-70. doi:10.1093/molehr/gah246

72. Heikkinen J, Möttönen M, Komi J, Alanen A, Lassila O. Phenotypic characterization of human decidual macrophages. Clin Exp Immunol (2003) 131:498-505. doi:10.1046/j.1365-2249.2003.02092.x

73. Jones BJ, Brooke G, Atkinson K, Mctaggart SJ. Immunosuppression by placental indoleamine 2,3-dioxygenase: a role for mesenchymal stem cells. Placenta (2007) 28:1174-81. doi:10.1016/j.placenta.2007.07.001

74. Blaschitz A, Maschke P, Gauster M, Dohr G, Ball HJ, Sedlmayr P. Expression of indoleamine 2,3 dioxygenase-2 (IDO2) at the human feto-maternal interface. Pteridines (2010) 21:31-2.

75. Correa RR, Barrilari SE, Guimaraes CS, Rossi E, Silva RC, Olegario JG, et al. Expression of the melatonin receptor and tryptophan hydroxylase in placentas of the fetus with intra-uterine stress. Eur J Obstet Gynecol Reprod Biol (2009) 147:234-6. doi:10.1016/j.ejogrb.2009.07.015

76. Yoshida R, Hayaishi O. Induction of pulmonary indoleamine 2,3-dioxygenase by intraperitoneal injection of bacterial lipopolysaccharide. Proc Natl Acad Sci U S A (1978) 75:3998-4000. doi:10.1073/pnas.75.8.3998

77. Yoshida R, Urade Y, Tokuda M, Hayaishi O. Induction of indoleamine 2,3dioxygenase in mouse lung during virus infection. Proc Natl Acad Sci U S A (1979) 76:4084-6. doi:10.1073/pnas.76.8.4084

78. Yoshida R, Imanishi J, Oku T, Kishida T, Hayaishi O. Induction of pulmonary indoleamine 2,3-dioxygenase by interferon. Proc Natl Acad Sci U S A (1981) 78:129-32. doi:10.1073/pnas.78.1.129

79. Kane CD, Vena RM, Ouellette SP, Byrne GI. Intracellular tryptophan pool sizes may account for differences in gamma interferon-mediated inhibition and persistence of chlamydial growth in polarized and nonpolarized cells. Infect Immun (1999) 67:1666-71.

80. MacKenzie CR, Hucke C, Müller D, Seidel K, Takikawa O, Däubener W. Growth inhibition of multiresistant enterococci by interferon-gamma-activated human uro-epithelial cells. J Med Microbiol (1999) 48:935-41. doi:10.1099/0022261548-10-935

81. Däubener W, Schmidt SK, Heseler K, Spekker KH, Mackenzie CR. Antimicrobial and immunoregulatory effector mechanisms in human endothelial cells. 
Indoleamine 2,3-dioxygenase versus inducible nitric oxide synthase. Thromb Haemost (2009) 102:1110-6. doi:10.1160/TH09-04-0250

82. Munn DH, Mellor AL. Indoleamine 2,3 dioxygenase and metabolic control of immune responses. Trends Immunol (2013) 34:137-43. doi:10.1016/j.it.2012. 10.001

83. Opitz CA, Litzenburger UM, Sahm F, Ott M, Tritschler I, Trump S, et al. An endogenous tumour-promoting ligand of the human aryl hydrocarbon receptor. Nature (2011) 478:197-203. doi:10.1038/nature10491

84. DiNatale BC, Murray IA, Schroeder JC, Flaveny CA, Lahoti TS, Laurenzana EM, et al. Kynurenic acid is a potent endogenous aryl hydrocarbon receptor ligand that synergistically induces interleukin-6 in the presence of inflammatory signaling. Toxicol Sci (2010) 115:89-97. doi:10.1093/toxsci/kfq024

85. Mimura J, Ema M, Sogawa K, Fujii-Kuriyama Y. Identification of a novel mechanism of regulation of Ah (dioxin) receptor function. Genes Dev (1999) 13:20-5. doi:10.1101/gad.13.1.20

86. Mezrich JD, Fechner JH, Zhang X, Johnson BP, Burlingham WJ, Bradfield CA. An interaction between kynurenine and the aryl hydrocarbon receptor can generate regulatory T cells. J Immunol (2010) 185:3190-8. doi:10.4049/jimmunol. 0903670

87. Vogel CF, Goth SR, Dong B, Pessah IN, Matsumura F. Aryl hydrocarbon receptor signaling mediates expression of indoleamine 2,3-dioxygenase. Biochem Biophys Res Commun (2008) 375:331-5. doi:10.1016/j.bbrc.2008.07.156

88. Jux B, Kadow S, Esser C. Langerhans cell maturation and contact hypersensitivity are impaired in aryl hydrocarbon receptor-null mice. J Immunol (2009) 182:6709-17. doi:10.4049/jimmunol.0713344

89. Nguyen NT, Kimura A, Nakahama T, Chinen I, Masuda K, Nohara K, et al. Aryl hydrocarbon receptor negatively regulates dendritic cell immunogenicity via a kynurenine-dependent mechanism. Proc Natl Acad Sci U S A (2010) 107:19961-6. doi:10.1073/pnas.1014465107

90. Yan Y, Zhang GX, Gran B, Fallarino F, Yu S, Li H, et al. IDO upregulates regulatory $\mathrm{T}$ cells via tryptophan catabolite and suppresses encephalitogenic $\mathrm{T}$ cell responses in experimental autoimmune encephalomyelitis. J Immunol (2010) 185:5953-61. doi:10.4049/jimmunol.1001628

91. Lee WS, Lee SM, Kim MK, Park SG, Choi IW, Choi I, et al. The tryptophan metabolite 3-hydroxyanthranilic acid suppresses $\mathrm{T}$ cell responses by inhibiting dendritic cell activation. Int Immunopharmacol (2013) 17:721-6. doi:10.1016/j.intimp.2013.08.018

92. Metz R, Rust S, Duhadaway JB, Mautino MR, Munn DH, Vahanian NN, et al. IDO inhibits a tryptophan sufficiency signal that stimulates mTOR: a novel IDO effector pathway targeted by D-1-methyl-tryptophan. Oncoimmunology (2012) 1:1460-8. doi:10.4161/onci.21716

93. Munn DH, Sharma MD, Baban B, Harding HP, Zhang Y, Ron D, et al. GCN2 kinase in $\mathrm{T}$ cells mediates proliferative arrest and anergy induction in response to indoleamine 2,3-dioxygenase. Immunity (2005) 22:633-42. doi:10.1016/j.immuni.2005.03.013

94. Fleckner J, Martensen PM, Tolstrup AB, Kjeldgaard NO, Justesen J. Differential regulation of the human, interferon inducible tryptophanyl-tRNA synthetase by various cytokines in cell lines. Cytokine (1995) 7:70-7. doi:10.1006/cyto. 1995.1009

95. Boasso A, Herbeuval JP, Hardy AW, Winkler C, Shearer GM. Regulation of indoleamine 2,3-dioxygenase and tryptophanyl-tRNA-synthetase by CTLA-4Fc in human CD4+ T cells. Blood (2005) 105:1574-81. doi:10.1182/blood2004-06-2089

96. Sundrud MS, Koralov SB, Feuerer M, Calado DP, Kozhaya AE, Rhule-Smith A, et al. Halofuginone inhibits TH17 cell differentiation by activating the amino acid starvation response. Science (2009) 324:1334-8. doi:10.1126/science. 1172638

97. Fallarino F, Grohmann U, You S, Mcgrath BC, Cavener DR, Vacca C, et al. The combined effects of tryptophan starvation and tryptophan catabolites down-regulate $\mathrm{T}$ cell receptor zeta-chain and induce a regulatory phenotype in naive T cells. J Immunol (2006) 176:6752-61. doi:10.4049/jimmunol.176.11. 6752

98. Pallotta MT, Orabona C, Volpi C, Vacca C, Belladonna ML, Bianchi R, et al. Indoleamine 2,3-dioxygenase is a signaling protein in long-term tolerance by dendritic cells. Nat Immunol (2011) 12:870-8. doi:10.1038/ni.2077

99. Munn DH, Zhou M, Attwood JT, Bondarev I, Conway SJ, Marshall B, et al. Prevention of allogeneic fetal rejection by tryptophan catabolism [see comments]. Science (1998) 281:1191-3. doi:10.1126/science.281.5380.1191
100. Mellor AL, Sivakumar J, Chandler P, Smith K, Molina H, Mao D, et al. Prevention of T cell-driven complement activation and inflammation by tryptophan catabolism during pregnancy. Nat Immunol (2001) 2:64-8. doi:10.1038/83183

101. Aluvihare VR, Kallikourdis M, Betz AG. Regulatory T cells mediate maternal tolerance to the fetus. Nat Immunol (2004) 5:266-71. doi:10.1038/ni1037

102. Uyttenhove C, Pilotte L, Theate I, Stroobant V, Colau D, Parmentier N, et al. Evidence for a tumoral immune resistance mechanism based on tryptophan degradation by indoleamine 2,3-dioxygenase.[see comment]. Nat Med (2003) 9:1269-74. doi:10.1038/nm934

103. Smith JR, Evans KJ, Wright A, Willows RD, Jamie JF, Griffith R. Novel indoleamine 2,3-dioxygenase-1 inhibitors from a multistep in silico screen. Bioorg Med Chem (2012) 20:1354-63. doi:10.1016/j.bmc.2011.10.068

104. Perkins MN, Stone TW. An iontophoretic investigation of the actions of convulsant kynurenines and their interaction with the endogenous excitant quinolinic acid. Brain Res (1982) 247:184-7. doi:10.1016/0006-8993(82)91048-4

105. Perkins MN, Stone TW. Pharmacology and regional variations of quinolinic acid-evoked excitations in the rat central nervous system. J Pharmacol Exp Ther (1983) 226:551-7.

106. Hilmas C, Pereira EF, Alkondon M, Rassoulpour A, Schwarcz R, Albuquerque EX. The brain metabolite kynurenic acid inhibits alpha7 nicotinic receptor activity and increases non-alpha7 nicotinic receptor expression: physiopathological implications. J Neurosci (2001) 21:7463-73.

107. Christen S, Peterhans E, Stocker R. Antioxidant activities of some tryptophan metabolites: possible implication for inflammatory diseases. Proc Natl Acad Sci US A (1990) 87:2506-10. doi:10.1073/pnas.87.7.2506

108. Wang Q, Zhang M, Ding Y, Wang Q, Zhang W, Song P, et al. Activation of $\mathrm{NAD}(\mathrm{P}) \mathrm{H}$ oxidase by tryptophan-derived 3-hydroxykynurenine accelerates endothelial apoptosis and dysfunction in vivo. Circ Res (2014) 114:480-92. doi:10.1161/CIRCRESAHA.114.302113

109. Yuasa HJ, Ball HJ. Indoleamine 2,3-dioxygenases with very low catalytic activity are well conserved across kingdoms: IDOs of Basidiomycota. Fungal Genet Biol (2013) 56:98-106. doi:10.1016/j.fgb.2013.03.003

110. Lo BK, Jalili RB, Zloty D, Ghahary A, Cowan B, Dutz JP, et al. CXCR3 ligands promote expression of functional indoleamine 2,3-dioxygenase in basal cell carcinoma keratinocytes. Br J Dermatol (2011) 165:1030-6. doi:10.1111/j. 1365-2133.2011.10489.x

111. Tankiewicz A, Pawlak D, Topczewska-Bruns J, Buczko W. Kidney and liver kynurenine pathway enzymes in chronic renal failure. Adv Exp Med Biol (2003) 527:409-14. doi:10.1007/978-1-4615-0135-0_48

112. Badawy AA. Possible involvement of the enhanced tryptophan pyrrolase activity in the corticosterone- and starvation-induced increases in concentrations of nicotinamide-adenine dinucleotides (phosphates) in rat liver. Biochem J (1981) 196:217-24.

113. Kanai M, Funakoshi H, Takahashi H, Hayakawa T, Mizuno S, Matsumoto $\mathrm{K}$, et al. Tryptophan 2,3-dioxygenase is a key modulator of physiological neurogenesis and anxiety-related behavior in mice. Mol Brain (2009) 2:8. doi:10.1186/1756-6606-2-8

114. Nowak EC, De Vries VC, Wasiuk A, Ahonen C, Bennett KA, Le Mercier I, et al. Tryptophan hydroxylase-1 regulates immune tolerance and inflammation. J Exp Med (2012) 209:2127-35. doi:10.1084/jem.20120408

115. Knolle PA. Cognate interaction between endothelial cells and T cells. Results Probl Cell Differ (2006) 43:151-73. doi:10.1007/400_018

116. Beutelspacher SC, Tan PH, Mcclure MO, Larkin DF, Lechler RI, George AJ. Expression of indoleamine 2,3-dioxygenase (IDO) by endothelial cells: implications for the control of alloresponses. Am J Transplant (2006) 6:1320-30. doi:10.1111/j.1600-6143.2006.01324.x

117. Kudo Y, Boyd CA, Sargent IL, Redman CW. Decreased tryptophan catabolism by placental indoleamine 2,3-dioxygenase in preeclampsia. Am J Obstet Gyn. (2003) 188:719-26. doi:10.1067/mob.2003.156

118. Nishizawa H, Hasegawa K, Suzuki M, Kamoshida S, Kato T, Saito K, et al. The etiological role of allogeneic fetal rejection in pre-eclampsia. Am J Reprod Immunol (2007) 58:11-20. doi:10.1111/j.1600-0897.2007.00484.x

119. Liu X, Liu Y, Ding M, Wang X. Reduced expression of indoleamine 2,3dioxygenase participates in pathogenesis of preeclampsia via regulatory $\mathrm{T}$ cells. Mol Med Rep (2011) 4:53-8. doi:10.3892/mmr.2010.395

120. Schröcksnadel H, Baier-Bitterlich G, Dapunt O, Wachter H, Fuchs D. Decreased plasma tryptophan in pregnancy. Obstet Gynecol (1996) 88:47-50. doi:10.1016/ 0029-7844(96)00084- 1 
121. Nishizawa H, Hasegawa K, Suzuki M, Achiwa Y, Kato T, Saito K, et al. Mouse model for allogeneic immune reaction against fetus recapitulates human preeclampsia. J Obstet Gynaecol Res (2008) 34:1-6. doi:10.1111/j.1447-0756.2007. 00679.x

122. Nishizawa H, Suzuki M, Pryor-Koishi K, Sekiya T, Tada S, Kurahashi H, et al. Impact of indoleamine 2,3-dioxygenase on the antioxidant system in the placentas of severely pre-eclamptic patients. Syst Biol Reprod Med (2011) 57:174-8. doi:10.3109/19396368.2011.587590

123. Kamimura S, Eguchi K, Yonezawa M, Sekiba K. Localization and developmental change of indoleamine 2,3-dioxygenase activity in the human placenta. Acta Med Okayama (1991) 45:135-9.

124. Arck PC, Ferrick DA, Steele-Norwood D, Croitoru K, Clark DA. Murine T cell determination of pregnancy outcome: I. Effects of strain, alphabeta T cell receptor, gammadelta $\mathrm{T}$ cell receptor, and gammadelta $\mathrm{T}$ cell subsets. Am J Reprod Immunol (1997) 37:492-502. doi:10.1111/j.1600-0897.1997.tb00265.x

125. Hansen AM, Ball HJ, Mitchell AJ, Miu J, Takikawa O, Hunt NH. Increased expression of indoleamine 2,3-dioxygenase in murine malaria infection is predominantly localised to the vascular endothelium. Int J Parasitol (2004) 34:1309-19. doi:10.1016/j.ijpara.2004.07.008

126. Schroten H, Spors B, Hucke C, Stins M, Kim KS, Adam R, et al. Potential role of human brain microvascular endothelial cells in the pathogenesis of brain abscess: inhibition of Staphylococcus aureus by activation of indoleamine 2,3-dioxygenase. Neuropediatrics (2001) 32:206-10. doi:10.1055/s-2001-17375

Conflict of Interest Statement: The authors declare that the research was conducted in the absence of any commercial or financial relationships that could be construed as a potential conflict of interest.

Received: 28 March 2014; paper pending published: 11 April 2014; accepted: 05 May 2014; published online: 19 May 2014.

Citation: Sedlmayr P, Blaschitz A and Stocker $R$ (2014) The role of placental tryptophan catabolism. Front. Immunol. 5:230. doi: 10.3389/fimmu.2014.00230

This article was submitted to Inflammation, a section of the journal Frontiers in Immunology.

Copyright (c) 2014 Sedlmayr, Blaschitz and Stocker. This is an open-access article distributed under the terms of the Creative Commons Attribution License (CC BY). The use, distribution or reproduction in other forums is permitted, provided the original author(s) or licensor are credited and that the original publication in this journal is cited, in accordance with accepted academic practice. No use, distribution or reproduction is permitted which does not comply with these terms. 